\title{
THE OCCURRENCE OF "EMPATHICED, MODERN" BUILDINGS INSIDE TRADITIONAL ENVIRONMENT IN BOTI VILLAGE, TIMOR ISLAND
}

\author{
SARASWATI, Titien \\ Faculty of Architecture and Design, Duta Wacana Christian University, \\ Jalan dr. Wahidin Sudirohusodo No. 5-25, Yogyakarta 55224, Tel. (0247) 563929 \\ Corresponding author; Email: titiens@staff.ukdw.ac.id; titiens10@gmail.com
}

\begin{abstract}
Boti village occupied by Boti tribe, located in hilly, remote area in Timor Island, Eastern Indonesia. Boti village is known for its ancient, traditional environment, and most of the buildings there can be categorized as vernacular buildings. Interestingly, there are also "modern" buildings erected there. The objective of this paper is to show, that by empathically understanding the way of life of different people by the head of Boti tribe, it is possible to construct "modern" buildings in Boti village.
\end{abstract}

Keywords: Traditional; vernacular; modern building.

\section{INTRODUCTION}

Boti village is known for its ancient, traditional environment. The people there have their own "religion", namely Halaika which can be categorized "animism". The Halaika will be played an important roles to all the way of life of the people there. Whenever somebody violates the rules, then he or she should be out from the village, lives outside the village. This happened to the eldest son of the King of Boti. He (the eldest son) would be appointed to be the King of Boti later. But he adhered to Catholic religion, then he evicted from Boti village. And his younger brother then was appointed to be the King of Boti, his name is Nama Benu.

Domenig (2014) explains that there is the fact that there are also many ethnographic sources that refer to times when ethnic groups which built vernacular houses still adhered partly to their indigenous religions. Accordingly, in my opinion, this statement is fit enough to the above situation in Boti village.

There is no literature nor books about Boti village. According to Saraswati (2013a), traditional architecture and vernacular buildings can be distinguished from their aesthetic value. The highest, grandly scaled aesthetic value is for classical architecture (one type of traditional architecture); whereas the lowest, humbly scaled aesthetic value is for vernacular building. This point supported by Brunskill's statement (2000) that aesthetic considerations in vernacular buildings, though present to some small degree, being quite minimal. Accordingly,
Saraswati (2013a) concluded that all buildings in Boti village - except the "modern" buildings - can be categorized vernacular buildings.

As aforementioned, there are also "modern" buildings in spite of vernacular buildings in Boti village: homestay, PKK office, gallery, building for workshop, and bathroom. Then questions in mind are: Why such "modern" buildings can be erected in Boti village in spite of Boti's ancient tradition? What was the role of the King of Boti in developing these "modern" buildings?

\section{METHODS}

Using multiplicity methods: collecting data conducted by field survey, documenting the buildings physically both vernacular and "modern" buildings, directly interviewing the King of Boti. Method of analysis by examining vernacular and "modern" buildings with the way of life of the people there.

According to the rules there, all information for the people who visit Boti village should be provided by the King of Boti himself, or other persons who have already appointed by the King of Boti to give information. So that the researcher could not give questionnaires nor asked questions to the people there.

\section{SURVEY RESULT AND DISCUSSION}

First of all I would like to clarify the term "modern" and "traditional" buildings. Here "modern" building means the building which has new form, alike in the town outside and nearby Boti village. And 
this building also has new function that never occurred before in Boti village. The materials of the building also a bit differ from that of building in Boti village. Whereas the "traditional" - in this case is vernacular - building here, according to Brunskill (2000), means that the building designed by an amateur without any training in design, the individual will have been guided by a series of conventions built up in his locality. Local materials would be used as a matter of course, other materials being chosen and imported quite exceptionally. Furthermore, Noble (2007) mentions that traditional architecture is passed down from person to person, generation to generation, particularly orally. Brunskill (1993) also states that vernacular buildings are not only dwellings but also farm buildings.

There are generally two types of vernacular buildings in Boti village: Lopo and Ume Kbubu. Lopo can be categorized as the Main Lopo and the King's Lopo for the guests. There are also public kitchen, and some spaces with fences to keep the crops, and also to keep the live stocks (pigs, hens, ducks).

\section{Vernacular buildings and the way of life of the people}

The existence of vernacular buildings cannot be far from the way of life along with the traditional rules of the people in Boti village. Whenever the adult man would like to marry, he has to built one Lopo and one Ume Kbubu. The location of the Lopo and Ume Kbubu is on the land owned by his parents. The land is divided by the number of the sons the parents have. From this point then, it can be shown how the vernacular buildings (Lopo and Ume Kbubu) still have their existences. Here are the photographs of the Lopo in the following (Figure 1 and Figure 2).

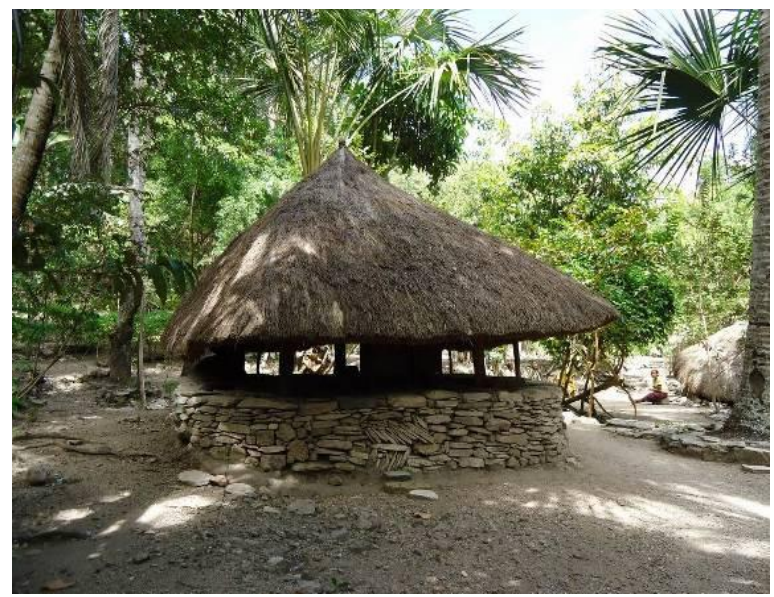

Figure 1. Lopo
The plan of Lopo is circular. Lopo is usually for gathering and entertaining the visitors, the guests. Lopo has conical roof. The roof of the Lopo is very low, so that the guests should lower their heads when entering the Lopo. So is the ceiling is very low, about 165 centimeters from the Lopo's floor. The floor is from the stones that piled uniquely, as in the photograph. The roof is thatched by grasses (alangalang) or gewang leaves which can be found in abundant there. This brings into line with, to repeat, Brunskill (2000) points out that local materials would be used as a matter of course, other materials being chosen and imported quite exceptionally.

Forth (2003) explains about traditional, vernacular building in Nage, central Flores Island. He states that the traditional house is constructed of wood, bamboo, and thatch (straw roofing). Furthermore, Oliver (2003) points out that many vernacular houses thatched with bundled and tied of certain grasses or reeds. This can be applied for the roof covering and or wall covering. Saraswati (2013b) on her book based on her research on vernacular buildings, explains that tobacco drying barns in Jawa are also thatched by bundled of dried sugar-cane leaves. These materials of roofings are similar to grasses or reeds. Accordingly, here the roof of the Lopo is thatched by grasses or gewang leaves as aforementioned. Here the Lopo is open, without enclosure.

In the night Lopo can be used to be the place when the people entertaining the guests. Musicians sit in the Lopo playing their music, the dancers dancing in the front of the musicians. The guests can sit in the Lopo or stand up next to the Lopo, even the guest also can participate to dance along with the dancers. Other vernacular building is Ume Kbubu as in the following photograph (Figure 3 and Figure 4).

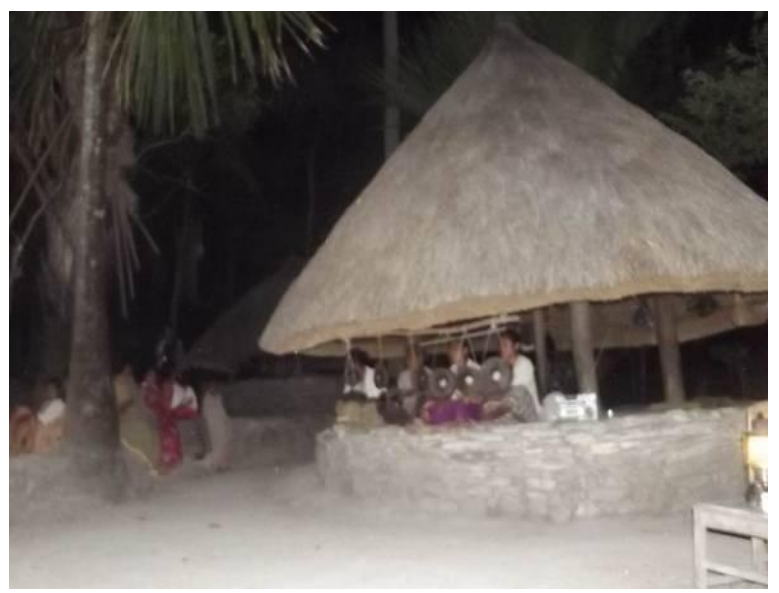

Figure 2. The musicians entertaining the guest in the night in the Lopo 


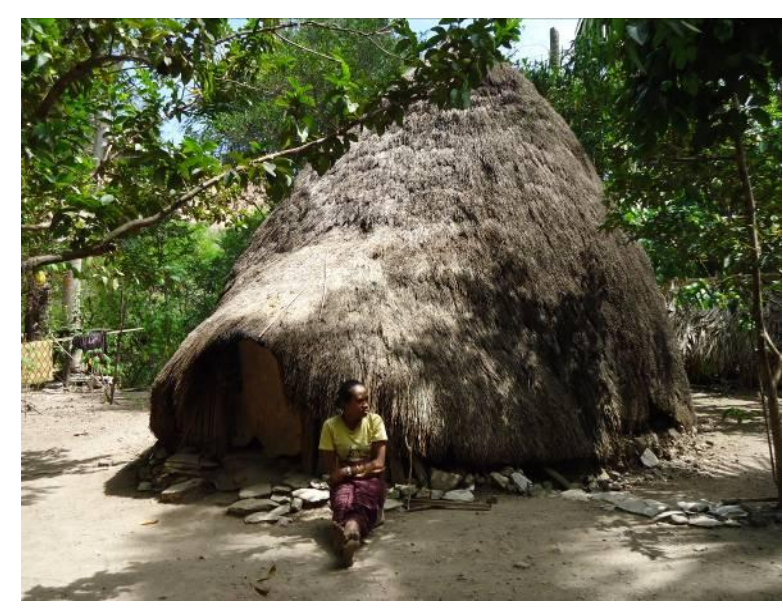

Figure 3. The front of Ume Kbubu with its door

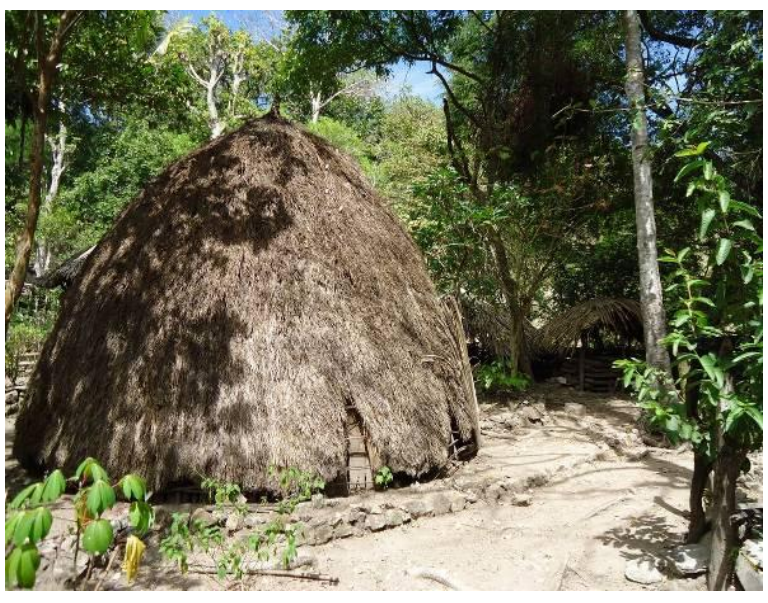

Figure 4. The back side of Ume Kbubu

Ume Kbubu is really a place to keep food and other possession, and a place to relax and sleep for its owners. As stated by Brunskill (1993) aforementioned, vernacular buildings are not only dwellings but also farms buildings. In this case here Ume Kbubu can be a building to keep harvested crops. Ume Kbubu means round house. The plan of Ume Kbubu is circular, and there is a small, half round space used as a place for the small door to enter the Ume Kbubu. The door is very low, about one meter from the ground. So that the owners should bow or lower their bodies when entering Ume Kbubu. No other door except this small one, and it is also closed in the whole day. The roof is thatched by grasses or gewang leaves directly from the upper part to the ground, so that the roof also has the function as the wall. This condition very much matches to Oliver (2003) statement above. So it is very much contradiction that Ume Kbubu is enclosed, while the Lopo is open building without enclosure.

Inside Ume Kbubu there are five areas: area for the door, area for keeping the tools and kitchen utensils in the back side inside Ume Kbubu, area for sleeping in the left and right part inside Ume Kbubu, and area for cooking in the middle part inside Ume Kbubu. The raw food is also kept inside too, such as corn, rice, and umbi-umbian (tuber, tap-root).

\section{The role of the King of Boti}

According to the people outside Boti village, the King of Boti is very much respected by the people in Boti village. Furthermore, the King also has "supernatural power" that no other people have. That is why all of the King's order will be followed directly by his people. Also, all data presented here had been collected after the King allowed us (the researchers) to collect information. It is also possible that other people who would like to survey there will not be permitted to collect data by the King. And this situation has already happen to other researchers. The main thing we are told by the people outside Boti village was, when we would like to visit Boti village, we have to have a pure, nice heart, and no other any negative purposes in our mind. The King of Boti with his supernatural power has already known who will visit Boti village and what is the aim of the visitors or the researchers, before the visitors reach the village. It is only one of the many greatness of the King's supernatural power.

The King of Boti very much adheres to the ancient Halaika belief, such as the rules that the adult man who would like to marry should prepare the buildings for his future family. So that the vernacular buildings (Lopo and Ume Kbubu) still have their existences, and also should be kept and maintained. All of the materials for these buildings are elsewhere around Boti village. And all the buildings are also erected with the help of other people there (or gotongroyong).

\section{New, "modern" buildings}

As mentioned earlier, there are also some "modern" buildings in Boti village. To repeat, here "modern" building means the building which has the new form, alike in the town outside Boti village; and which has new functions that never occurred before in Boti village. They are homestay, PKK office, gallery, building for workshop, and bathroom for the guests.

Here I would like to explain the homestay and PKK office only. The new "modern" buildings form square in the plans, the wall and the ceiling from the trunk (pelepah) of gewang trees. The roof is thatched by grasses and gewang leaves. The columns from wood. The form of the buildings are squares, but still 
have semi-conical roof, as in the following photographs.

Homestay (Figure 5) was built in the year of 2000 s, for the guests who want to stay overnight in Boti village. Of course the bathroom for the guests are using bathrooms' equipment as in the "modern" community outside Boti village. There are four rooms inside the homestay, each room has three beds. So that the capacity of the homestay can accommodate 12 people. Part of the building was painted with green colour.

Another "modern" building is PKK office in which PKK stands for Pendidikan Kesejahteraan Keluarga, means Family Welfare Education initiated Indonesia-wide by the government of Indonesia. This building as a mean of government (Timor Tengah Selatan Regency, or South-Middle Timor Regency) representation in Boti village. This is a building when the women of Boti village are trained and given the education to have a better, healthier family life by the government. The door and the windows of the building were painted with red colour as in the following photograph (Figure 6).

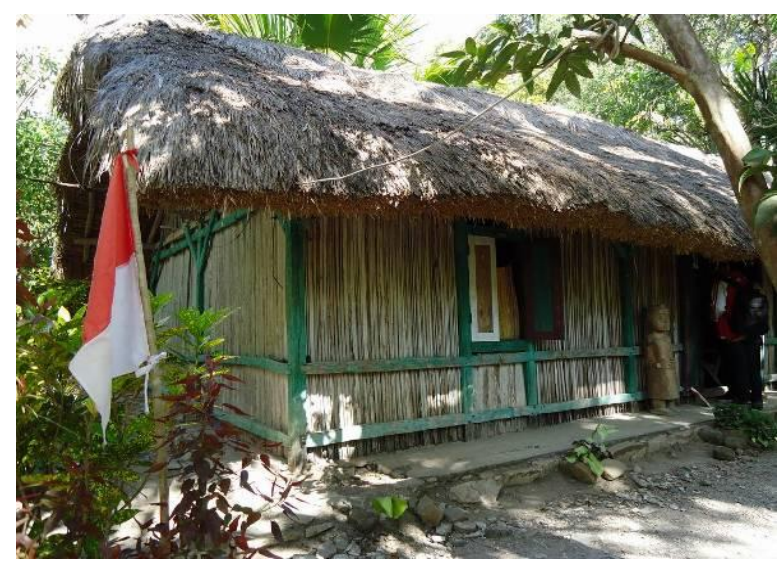

Figure 5. Homestay for the guests

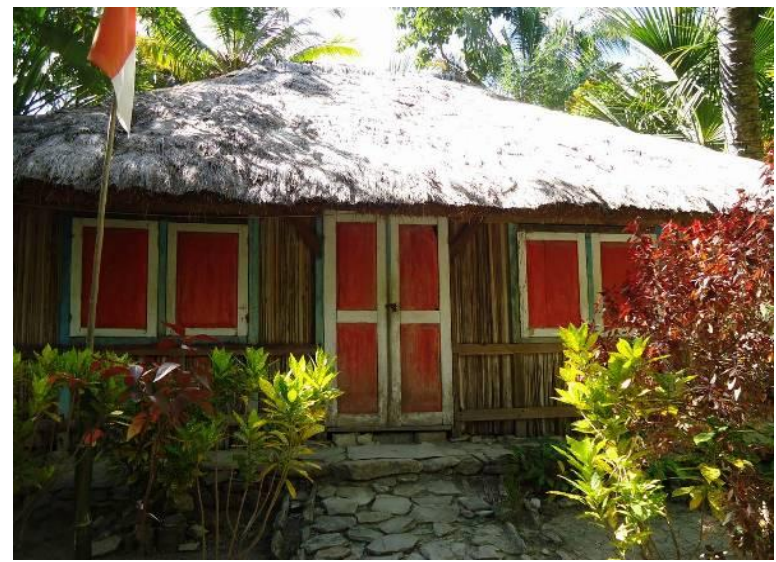

Figure 6. PKK office
The questions in mind, as mentioned earlier: Why such "modern" buildings can be constructed in Boti village? What was the role of the King of Boti in constructing these "modern" buildings?

\section{Empathically understanding}

As mentioned before, the King of Boti very much concerns to the life of his people. All he does only for his people according to the Halaika belief. So that it is not surprising when the vernacular buildings still exist there.

Now about the "modern" buildings: homestay and PKK office. Homestay is for the visitors or the guests who visit Boti village and stay overnight. Of course the visitors are the persons who have the way of life that is very much different from that of the people in Boti village, because the visitors come from both "modern" Indonesia's towns and foreign countries. They have different attitude and behaviour with the people of Boti village in their everyday life. For example how they eat, sleep, dress, take a bath, urinate, et cetera. That is why the homestay is provided with the beds including mattresses, the bathroom also provided with bathroom's equipments as in the "modern" bathroom (water closet, bath vessel with water) as in the following photograph (Figure 7).

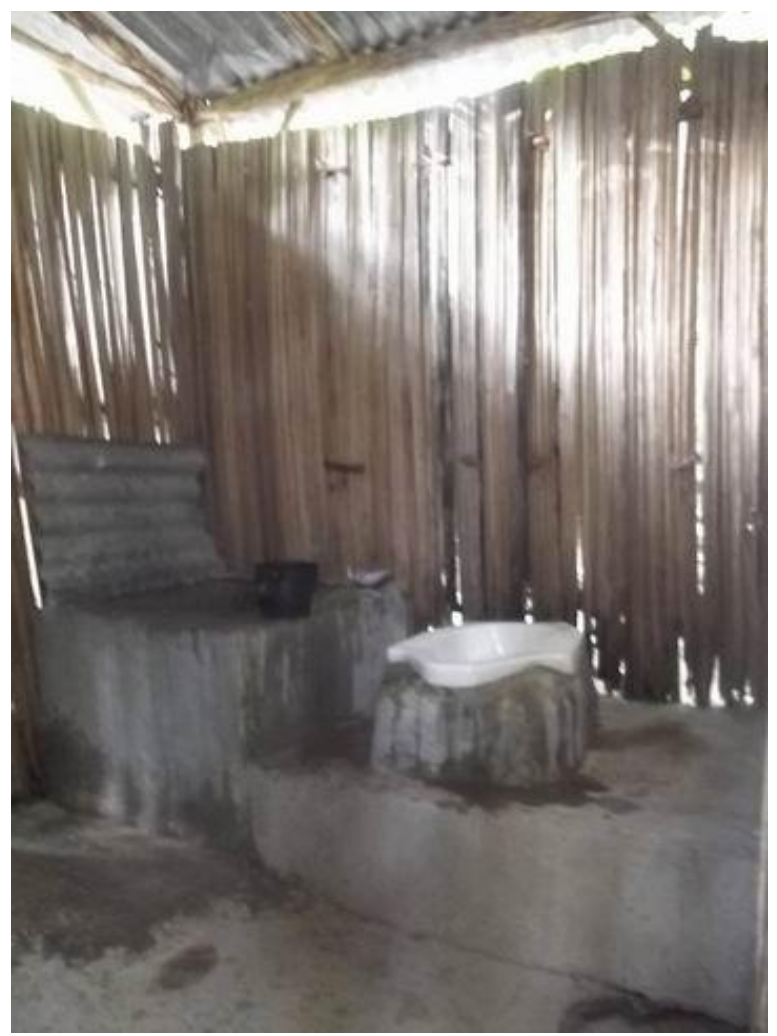

Figure 7. Bathroom for the guests/visitors 
The other "modern" building is PKK office. As mentioned earlier, the "modern" buildings was initiated by the government of Indonesia, in this case by the government of South-Middle Timor Regency (Kabupaten Timor Tengah Selatan). Boti village is under this regency's rule. PKK program specifically for the families, and the persons who are responsible for this are the women. Boti's women are trained in this building by the government's officers about how to have a better, healthier way of life, and if possible to have other income for the families.

Let's look at the advantages of these two buildings for Boti's people:

- Homestay for the visitors/the guests.

The visitors/the guests who stay overnight will stay in the homestay. They pay for the accommodation and for the meal provided by Boti's people. From this "business", the money can be kept for the needs for Boti's people to buy something for their life.

- PKK office

PKK office is used by Boti's women to learn and have a better, healthier life style trained by the government's officers. From this training, the women are hoped to have a better thought in rearing their families. With the advantage for the families of Boti's people, it seems that the King of Boti obey to the PKK program initiated by the government.

In this case, it seems that the King of Boti has empathically understood about "new buildings" that useful for his people.

According to Umbach and Huppauf (2005), vernacular modernism is better understood in terms of praxis. In other words, its significance is best captured by examining its role in those cultural fields that participate in the construction and performance of space and place. Here we can find out that the new, "modern" buildings in Boti village are still resembled the vernacular buildings there, as the roof coverings are still thatched by grasses or gewang leaves, and the walls and ceiling from the trunk of gewang trees.

Furthermore, as explained by Asquith and Vellinga (2006), more often than not, vernacular houses or buildings are regarded as obstacles on the road to progress, which should be replaced by house types and living patterns that fit western notions of basic housing needs. But here in this paper I find out, according to the above discussion, that the new, "modern" buildings there are not in the means to replace the vernacular ones. The new, "modern" buildings in Boti village are for the advantages for Boti people.

\section{CONCLUSION}

From the above advantages for Boti's people, it can be inferred that the King of Boti has empathically understood to other people's life style who live outside Boti village, and also for the needs to have a better family life for Boti's people. This is the main reason why those "modern" buildings have already been occurred in Boti village.

Therefore, this paper is not about the buildings that can be categorized "empathic", but about the buildings which need empathically understanding of something (culture, way of life) to be built. As empathy means projecting oneself into (and so fully understanding, and losing one's identity in) a work of art or other object of contemplation; it is the attitude and behaviour of the King of Boti and his people that have empathy to the culture, to the way of life of different people or different communities outside Boti village to develop such buildings. Therefore, empathic in design here can be concluded as the transformation of the way of life of other people that can be accommodated in buildings among environment that never constructs such buildings before without any coercions.

\section{AKNOWLEDGEMENTS}

My gratitude to my students who helped me conducted field surveys in Boti village: Agustonce Efraim Nabuasa, Xaverius Arnoldus Nggorong, and Anugrah Saputra Togatorop. Without them, it would have been impossible for me to have conducted this research.

\section{REFERENCES}

Asquith, L. and Vellinga, M. (2006). Vernacular Architecture in the Twenty-First Century. London and New York: Taylor \& Francis.

Brunskill, R. W. (1993). The Traditional Buildings of Cumbria. Companion to Contemporary Architectural Thought. London and New York: Routledge.

Brunskill. R. W. (2000). Illustrated Handbook of Vernacular Architecture $\left(4^{\text {th }}\right.$ ed). London: Faber and Faber.

Domenig, G. (2014). Religion and Architecture in Premodern Indonesia. Leiden: Koninlijke Brill $\mathrm{NV}$.

Forth, G. (2003). Change and Continuity in Nage House Form. Indonesian Houses. Leiden: KITLV Press.

Noble, A. G. (2007). Traditional Buildings: A Global Survey of Structural Forms and Cultural Functions. London: I.B. Tauris. 
Oliver, P. (2003). Dwellings. The Vernacular House World Wide. New York: Phaidon Press Limited.

Saraswati, T. (2013a). Perbedaan dan Persamaan Antara Bangunan Vernakular dan Arsitektur Tradisional (The Differences and the Similarities Between Vernacular Buildings and Traditional Architecture), Prosiding Seminar Nasional Reinterpretasi Identitas Arsitektur Nusantara (Proceedings of the National Seminar in Re-interpretation of the Identity of Nusantara
Architecture), 2-55 to 2-62, Udayana University Press, Denpasar - Bali, Indonesia.

Saraswati, T. (2013b). Bangunan Pengering Tembakau di Jawa. Seri Bangunan Vernacular (Tobacco Drying Barns in Java. Vernacular Buildings Series). Surabaya: Wastu Lanas Grafika.

Umbach, M. and Huppauf, B. (eds.) (2005). Vernacular Modernism. Stanford, CA: Stanford University Press. 